\title{
Value of quantitative pathological variables as prognostic factors in advanced ovarian carcinoma
}

\author{
M Brinkhuis, J P A Baak, G A Meijer, P J van Diest, O Mogensen, P Bichel, J P Neijt
}

\begin{abstract}
Aims-To evaluate correlations among clinical, pathological, morphometric, stereological, and DNA flow cytometric variables and their prognostic value in advanced ovarian cancer.

Methods-Tissue was collected from 180 patients with advanced ovarian cancer. All 180 had undergone debulking surgery and were being treated with cisplatin. Long term follow up was available for all patients. The mitotic activity index (MAI), volume $\%$ of epithelium (VPE), mean nuclear area (MNA), standard deviation of the nuclear area (SDNA), estimates of volume weighted mean nuclear volume $\left(\bar{v}_{\mathrm{v}}\right)$, and variables obtained from minimum spanning tree (MST) analysis were assessed in the least differentiated tumour section in each case. DNA flow cytometry was also performed.
\end{abstract} Results-Quantitative pathological features differed significantly with respect to histological grade. The MAI, MNA, SDNA, and the number of points connected to three neighbours differed significantly among the different DNA ploidy groups. The VPE and number of points connected to two or three neighbours differed significantly between FIGO stages III and IV. Fifty two (29\%) patients survived. FIGO stage, residual disease and SDNA had prognostic significance on both univariate and multivariate survival analysis. In patients with FIGO III stage disease and residual tumour nodes $\leq 2 \mathrm{~cm}$ in diameter (67 patients, 29 (43\%) survivors) a prognostic index was established based on SDNA and of the line length of the MST. The median survival time was not reached in a subgroup of patients with favourable prognosis (overall survival $57 \%$ ). Median survival was 32 months for patients with an unfavourable index score (overall survival $28 \%$ ).

Conclusion-Morphometric variables have important additional value in predicting prognosis in patients with advanced ovarian cancer.

(f Clin Pathol 1996;49:142-148)

Keywords: DNA flow cytometry, ovarian cancer, morphometry, prognosis.

Ovarian cancer is the fifth most common type of cancer diagnosed in women in the Netherlands and Denmark, with age standardised incidence rates of $14 \cdot 6$ and $15 \cdot 2$, respectively. ${ }^{12}$ The initial symptoms are usually non-specific and therefore most patients present with advanced disease. ${ }^{3}$ Despite recent improvements in treatment strategies for advanced ovarian malignancies, including optimal debulking surgery and cisplatin combination chemotherapy, ${ }^{4-6}$ clinical outcome is still fairly poor. Cisplatin has considerable side effects and a significant proportion of patients ultimately does not respond adequately to therapy. About $75 \%$ of these women will die of their disease; the median survival time is only two years. ${ }^{7}$ Objective variables that can accurately predict prognosis may be helpful for selecting patients who will benefit most from cisplatin therapy. Alternative treatment may be considered for other patients.

FIGO stage and performance status based on the Karnofsky index (KI) at initial diagnosis predict clinical outcome. ${ }^{8-10}$ The $\mathrm{KI}$, however, is based on subjective criteria and its prognostic relevance may therefore vary between different populations and evaluators. ${ }^{10}$ Optimally debulked patients with residual tumour nodes of less than $2 \mathrm{~cm}$ in diameter do better, ${ }^{5-8}$ possibly as the tumour is more accessible to cytotoxic drugs because of better vascularisation and oxygenation, and because the number of cycling cells is relatively larger than in bulky tumour masses. ${ }^{112}$ However, some patients with relatively favourable indicators of prognosis will die of recurrent disease. Histological grade is also of prognostic importance, ${ }^{7913}$ but cannot always be reproduced reliably. ${ }^{1415}$

Several studies have shown that quantitative pathological features, such as morphometric and stereological variables ${ }^{16-20}$ and DNA flow and image cytometric features, ${ }^{132122}$ are predictive of survival in patients with ovarian cancer undergoing treatment with cisplatin. An important advantage of these techniques is that objective and reproducible values are obtained. Moreover, these features are correlated with biological processes taking place in the tumour, such as genetic instability (DNA ploidy), proliferation (mitotic indices), nuclear differentiation (nuclear area, nuclear volume), and architectural differentiation (volume \% epithelium, minimum spanning tree analysis). Most of these studies have evaluated relatively small patient groups and the patients have not always been treated uniformly with cisplatin based chemotherapy and optimal surgery. Therefore, firm conclusions could not be drawn from these studies. The aim of the present study was to evaluate the prognostic value of clinical, pathological, morphometric, stereological, and DNA flow cytometric variables in 180 patients with advanced ovarian cancer. 


\section{Methods}

The patients and tissue included in the present study have also been included in previous studies. ${ }^{162023}$ The patients were between 26 and 70 years of age (median 54 years) at diagnosis. Of these patients, $140(78 \%)$ had FIGO stage III and $36(20 \%)$ had FIGO stage IV disease. The FIGO stage was unknown in four patients with advanced ovarian cancer. Disease was bulky (the diameter of the largest tumour node was greater than $5 \mathrm{~cm}$ ) at diagnosis in $105(81 \%)$ of 130 patients.

All of the patients underwent cytoreductive surgery and treatment with cisplatin combination chemotherapy. In $77(45 \%)$ of 172 patients the size of the largest tumour node was surgically reduced to $\leq 2 \mathrm{~cm}$; residual disease was $>2 \mathrm{~cm}$ in 95 patients. The postoperative residual disease status was unknown in eight patients. Seventy three patients received CAP-1 (cisplatin, doxorubicin and cyclophosphamide), 36 received CHAP-5 (cisplatin, doxorubicin, cyclophosphamide, and hexamethyl-melamine), 22 received CP (cisplatin and cyclophosphamide), and 49 were randomised for treatment with cisplatin and cyclophosphamide with or without adriamycin. No significant differences in survival were noted between the patients treated with the different chemotherapeutic regimens $(p=$ $0 \cdot 15)$.

Follow up information was available in all cases. Fifty two (29\%) patients survived. Median follow up in non-survivors was 21 months (range two to 82 months) and was 72 months (range 19 to 114 months) in survivors.

\section{TISSUE PROCESSING, QUALITATIVE AND} QUANTITATIVE METHODS

Tumour tissue was cut into slices $0.5 \mathrm{~cm}$ thick and fixed in $4 \%$ buffered formaldehyde. Haematoxylin and eosin stained sections, $4 \mu \mathrm{m}$ thick, were cut for diagnosis, morphometry and stereology. In each case a poorly differentiated, epithelium rich primary tumour section was selected for further quantitative analysis. An area measuring $0.5 \times 0.5 \mathrm{~cm}$ was chosen for analysis. This area was rich in epithelium and had the highest number of mitotic figures. Areas with necrosis, inflammation or calcification were avoided.

For DNA flow cytometry, sections $50 \mu \mathrm{m}$ thick were cut from the paraffin wax embedded tumour specimens; haematoxylin and eosin stained sandwich sections $4 \mu \mathrm{m}$ thick were checked for tumour content. The sections were processed routinely to obtain single cell suspensions according to standard procedures in the Netherlands ${ }^{1620}$ and Denmark. ${ }^{24}{ }^{25}$ Paraffin wax embedded material was not available for 47 patients, precluding DNA ploidy analysis.

All primary tumour sections were graded as well, moderately or poorly differentiated. ${ }^{26}$ Morphometric and stereological assessments were carried out as described previously. ${ }^{1623}$

The total number of mitotic figures was counted in 25 contiguous fields of vision with a conventional light microscope (final magnification $\times 400$, numerical aperture 0.75 , field diameter $450 \mu \mathrm{m})$. Once focused, no further adjustment was permitted. The total number of clearly identifiable mitotic figures, fulfilling the criteria described previously, ${ }^{27}$ was counted and taken as the mitotic activity index (MAI).

The volume percentage of epithelium (VPE) was estimated (final magnification $\times 200$, objective $\times 20$ ) using a 42 point parallel Weibel grid, assuming that the tissue was isotropic, uniform and randomly oriented. At least 300 points covering epithelial or stromal cells were counted in each tumour section. The percentage of points overlying epithelial cells was taken as the VPE.

Nuclear morphometric analysis was carried out using the PRODIT interactive digitising video overlay system (software version 5.1) (BMA, de Meern, The Netherlands). This system is composed of a video camera mounted on a microscope and linked to a video overlay board in a MS-DOS based computer. A final magnification on screen of approximately $\times 3000$ (objective $\times 100$ ) was used for assessing the mean nuclear area (MNA) and the volume weighted mean nuclear volume $\left(\bar{v}_{v}\right)$. An automatic scanning stage is linked to the system, which permits electronic demarcation of the measurement area and the random systematic selection of fields of vision. ${ }^{28}$ To assess the MNA, the contours of 100 nuclei were traced using the mouse in 100 randomly selected fields of vision in each case. Thus, the mean (MNA) and standard deviation of the nuclear area (SDNA) were calculated in each case. The estimation of the $\bar{v}_{v}$ was carried out as described elsewhere. ${ }^{29-33}$ Briefly, the intercepts of at least 90 nuclei in 14 fields of vision were measured. Thus, the intercepts were point sampled with a chance proportional to their volume. The unbiased estimate of $\bar{v}_{v}$ was then obtained by raising the measured mean intercept lengths to the third power and multiplying by $\pi / 3$.

Minimum spanning tree (MST) analysis was also performed using the PRODIT system. The final magnification displayed on the monitor was $\times 1900$ (objective $\times 63$ ). MST analysis was performed in 12 randomly selected fields of vision (each of which was $570 \times 570 \mu \mathrm{m}$ ). In each field of vision the centres of gravity of all tumour cell nuclei present within the same epithelial layer were marked. These points were then automatically connected by the minimal total line length without forming loops, thus forming the MST. The variables obtained from the MST were the number of points, total line length, average line length, minimum line length, maximum line length, standard deviation of the line length, and percentage of points connected to one neighbouring nucleus, two neighbouring nuclei and three neighbouring nuclei. ${ }^{34}$

The DNA index (DI) was calculated by dividing the channel numbers of the second and first $G_{0} / G_{1}$ peak, being 1.0 in case of a single peak. Based on their DI, tumours were classified as diploid $(\mathrm{DI}=1 \cdot 0)$, hyperdiploid $(1 \cdot 0<\mathrm{DI}<1 \cdot 9)$, tetraploid $(1 \cdot 9 \leq \mathrm{DI} \leq 2 \cdot 1)$, and

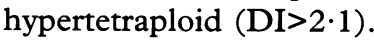


Table 1 Correlations among quantitative pathological features and histologic grade, FIGO stage and DNA ploidy

\begin{tabular}{|c|c|c|c|c|c|c|}
\hline \multirow[b]{3}{*}{ Variable } & \multicolumn{4}{|l|}{ Grade $(n=180)$} & \multirow{3}{*}{$\begin{array}{l}\text { FIGO stage }(n=176) \\
\text { Mann-Whitney p value } \\
I I I \text { v } I V\end{array}$} & \multirow{3}{*}{ 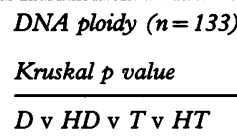 } \\
\hline & \multirow{2}{*}{$\frac{\text { Kruskal } p \text { value }}{I \mathrm{v} I I \mathrm{\vee} I I^{*}}$} & \multicolumn{3}{|c|}{ Mann-Whitney $p$ value } & & \\
\hline & & $I \mathrm{v} I I$ & $I \mathrm{v} I I I$ & $I I \mathrm{v} I I I$ & & \\
\hline $\begin{array}{l}\text { Mitotic activity index } \\
\text { Volume percentage epithelium } \\
\text { Mean nuclear area } \\
\text { Standard deviation of nuclear area } \\
\text { Volume weighted mean nuclear volume } \\
\text { DNA index }\end{array}$ & $\begin{array}{l}0.00001 \\
0.00001 \\
0.0003 \\
0.0005 \\
0.00001 \\
0.12\end{array}$ & $\begin{array}{l}\text { NS } \\
<0 \cdot 05 \\
\text { NS } \\
\text { NS } \\
\text { NS } \\
\text { NS }\end{array}$ & $\begin{array}{l}<0.05 \\
<0.05 \\
<0.05 \\
<0.05 \\
<0.05 \\
\text { NS }\end{array}$ & $\begin{array}{l}<0.05 \\
<0.05 \\
<0.05 \\
\text { NS } \\
<0.05 \\
\text { NS }\end{array}$ & $\begin{array}{l}0.09 \\
0.01 \\
0.79 \\
0.77 \\
0.57 \\
0.22\end{array}$ & $\begin{array}{l}0.01 \\
0.45 \\
0.05 \\
0.02 \\
0.30 \\
\text { NP }\end{array}$ \\
\hline $\begin{array}{l}\text { No. of points } \\
\text { Total line length }(\mu \mathrm{m}) \\
\text { Average line length }(\mu \mathrm{m}) \\
\text { Minimum line length }(\mu \mathrm{m}) \\
\text { Maximum line length }(\mu \mathrm{m}) \\
\text { SD of line length } \\
\text { Connected to one nucleus }(\%) \\
\text { Connected to two nuclei }(\%) \\
\text { Connected to three nuclei }(\%)\end{array}$ & $\begin{array}{l}0.00001 \\
0.00001 \\
0.00001 \\
0.0001 \\
0.0001 \\
0.13 \\
0.06 \\
0.00001 \\
0.00001\end{array}$ & $\begin{array}{l}\text { NS } \\
<0 \cdot 05 \\
\text { NS } \\
\text { NS } \\
\text { NS } \\
\text { NS } \\
\text { NS } \\
\text { NS } \\
\text { NS }\end{array}$ & $\begin{array}{l}<0.05 \\
<0.05 \\
<0.05 \\
<0.05 \\
<0.05 \\
\text { NS } \\
\text { NS } \\
<0.05 \\
<0.05\end{array}$ & $\begin{array}{l}<0.05 \\
<0.05 \\
<0.05 \\
<0.05 \\
\text { NS } \\
\text { NS } \\
\text { NS } \\
<0.05 \\
<0.05\end{array}$ & $\begin{array}{l}0.53 \\
0.93 \\
0.37 \\
0.36 \\
0.20 \\
0.36 \\
0.005 \\
0.006 \\
0.08\end{array}$ & $\begin{array}{l}0.24 \\
0.49 \\
0.44 \\
0.20 \\
0.70 \\
0.62 \\
0.75 \\
0.06 \\
0.02\end{array}$ \\
\hline
\end{tabular}

${ }^{*}$ Grade $\mathrm{I}=$ well differentiated, $\mathrm{II}=$ moderately differentiated, $\mathrm{III}=$ poorly differentiated; $\mathrm{DNA}$ ploidy: $\mathrm{D}=$ diploid; $\mathrm{HD}=$ hyperdiploid; $\mathrm{T}=$ tetraploid; $\mathrm{HT}=$ hypertetraploid; $\mathrm{SD}=$ standard deviation; $\mathrm{NS}=$ not significant; $\mathrm{NP}=$ not performed.

DATA EVALUATION

The differences in quantitative features between the three histological grades, DNA ploidy and FIGO stage were assessed using the Kruskal-Wallis and Mann-Whitney tests. The level of significance was set at $\mathrm{p}<0.05$.

For survival analysis, the time from diagnosis to death or last date of follow up was used as the overall survival time. Cut off points for the quantitative variables were chosen (1) to form three groups of equal size, (2) to form four groups of equal size and according to (3) the median value, (4) the percentage of surviving patients, and (5) previously established prognostically important thresholds (the thresholds resulting in the strongest prognostic value are shown). Kaplan-Meier curves were plotted and differences between the curves were tested for significance using the Mantel-Cox statistic. The additional prognostic value of features was assessed by the multivariate Cox regression model (enter and exit limits $0 \cdot 1$ ). Multivariate analysis was performed initially on the whole group, including FIGO stages III and IV. Thereafter, multivariate analysis was performed separately on the subgroups of patients with FIGO stage III disease, with residual tumour $\leq 2 \mathrm{~cm}$ in diameter, residual tumour $>2 \mathrm{~cm}$ in diameter, and with FIGO stage IV disease. Variables that reached significance in univariate analysis were used as categorical variables as determined by the established cut off point.

\section{Results}

Quantitative pathological features (especially the VPE and the total line length of the MST) were significantly different with respect to histological grades (table 1). The MAI, MNA, SDNA, and the number of points connected to three neighbouring nuclei differed significantly with respect to the different DNA ploidy groups. The VPE and number of points connected to two or three neighbouring nuclei differed significantly with respect to FIGO stage.

Univariate survival analysis demonstrated that FIGO stage was the best prognostic variable, followed by residual disease after surgery (table 2). Combining these two features pro-

Table 2 Results of survival analysis for clinicopathological variables in 180 patients with advanced overian cancer

\begin{tabular}{|c|c|c|c|c|c|}
\hline \multirow[b]{2}{*}{ Variable } & \multirow[b]{2}{*}{$n$} & \multicolumn{4}{|c|}{ Survival } \\
\hline & & $\%$ & $\begin{array}{l}\text { Median time } \\
\text { (months) }\end{array}$ & $\begin{array}{l}\text { Mantel-Cox } \\
\text { statistic }\end{array}$ & $p$ value \\
\hline $\begin{array}{l}\text { FIGO stage } \\
\text { III } \\
\text { IV } \\
\text { Unknown }\end{array}$ & $\begin{array}{c}140(80 \%) \\
36(20 \%) \\
4\end{array}$ & $\begin{array}{l}32 \\
11\end{array}$ & $\begin{array}{l}35 \\
17\end{array}$ & $23 \cdot 4$ & 0.00001 \\
\hline $\begin{array}{l}\text { Residual disease } \\
\leq 2 \mathrm{~cm} \\
>2 \mathrm{~cm} \\
\text { Unknown }\end{array}$ & $\begin{array}{c}77(45 \%) \\
95(55 \%) \\
8\end{array}$ & $\begin{array}{l}40 \\
19\end{array}$ & $\begin{array}{l}48 \\
23\end{array}$ & $14 \cdot 2$ & 0.0002 \\
\hline $\begin{array}{l}\text { FIGO and residual diseas } \\
\text { FIGO III, RD } \leq 2 \mathrm{~cm} \\
\text { FIGO III, RD }>2 \mathrm{~cm} \\
\text { FIGO IV }\end{array}$ & $\begin{array}{l}67(39 \%) \\
69(40 \%) \\
36(21 \%)\end{array}$ & $\begin{array}{l}43 \\
23 \\
11\end{array}$ & $\begin{array}{l}55 \\
29 \\
17\end{array}$ & 30 & 0.00001 \\
\hline $\begin{array}{l}\text { Grade } \\
\text { I } \\
\text { II } \\
\text { III }\end{array}$ & $\begin{array}{r}21(12 \%) \\
40(22 \%) \\
119(66 \%)\end{array}$ & $\begin{array}{l}52 \\
18 \\
29\end{array}$ & $\begin{array}{l}50 \\
32 \\
29\end{array}$ & $\begin{array}{l}5 \cdot 46 \\
5 \cdot 0^{*}\end{array}$ & $\begin{array}{l}0.07 \\
0.03^{*}\end{array}$ \\
\hline $\begin{array}{l}\text { Bulky disease status } \\
\leq 5 \mathrm{~cm} \\
>5 \mathrm{~cm} \\
\text { Unknown }\end{array}$ & $\begin{array}{r}25 \\
105 \\
50\end{array}$ & $\begin{array}{l}48 \\
27\end{array}$ & $\begin{array}{l}51 \\
24\end{array}$ & $3 \cdot 8$ & 0.05 \\
\hline
\end{tabular}

* Grade I $v$ grades II and III. 


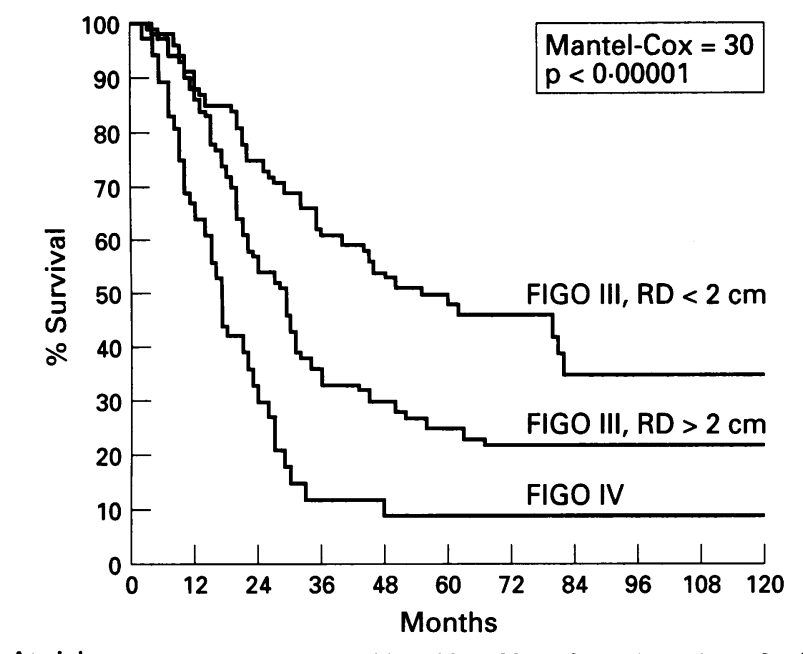

$\begin{array}{rrrrrrrrrrrll}\text { At risk } & 67 & 61 & 50 & 40 & 32 & 28 & 20 & 9 & 4 & 1 & 0 & \text { FIGO III, RD }<2 \mathrm{~cm} \\ & 69 & 61 & 39 & 24 & 18 & 15 & 12 & 5 & 1 & 1 & 0 & \text { FIGO III, RD }>2 \mathrm{~cm} \\ & 36 & 24 & 11 & 4 & 4 & 2 & 1 & 1 & 0 & 0 & 0 & \text { FIGO IV }\end{array}$

Figure 1 Survival curves for 180 patients with advanced ovarian cancer, combining FIGO stage and residual disease status (FIGO III, residual disease (RD) $<2 \mathrm{~cm} ;$ FIGO III, residual disease $>2 \mathrm{~cm}$; FIGO stage IV).

vided even more significant prognostic information on survival (fig 1). Bulky disease prior to surgery was less significant than the residual disease status after the debulking operation. Patients with well differentiated tumours survived significantly longer compared with patients with moderately and poorly differentiated tumours.

The results of survival analysis for the quantitative pathological and MST variables which reached significance overall and in the relevant subgroups are presented in tables 3 and 4 . The standard deviations of the nuclear area and of line length of the MST had important prognostic power overall in the subgroups of patients with FIGO stage III disease and residual tumour $<2 \mathrm{~cm}$ in diameter. In FIGO stage IV disease only the MST variables total line length and the number of points connected to one neighbouring nucleus had prognostic power.

Table 5 shows the results of the multivariate analysis. When entering the clinical, pathological and quantitative variables, the FIGO stage was selected first, followed by residual disease and SDNA. This resulted in the FRS index as follows: $(0.8856 \times \mathrm{FIGO})+(0.6035 \times$ residual disease $)+(0.5993 \times$ SDNA $)(F I G O=$ 3 or 4 ; residual disease $=1(\leq 2 \mathrm{~cm})$ or 2 $(>2 \mathrm{~cm})$, SDNA $\leq 19 \cdot 6=1$ or $>19 \cdot 6=2)$. Using this multivariate index three highly significant prognostic groups could be distinguished (Mantel-Cox $=35, \mathrm{p}<0.00001$ ).

In patients with FIGO stage III disease and with residual disease $<2 \mathrm{~cm}$ in diameter $(n=67)$, the SDNA was selected first, followed by SD of line length (SDLL) of the MST. The

Table 3 Results of survival analysis of quantitative pathological variables in each of the relevant substages (FIGO stage III and residual disease (RD) less than $2 \mathrm{~cm}$, FIGO stage III and RD greater than $2 \mathrm{~cm}, F I G O$ stage IV) (only variables that reached significance are listed)

\begin{tabular}{|c|c|c|c|c|c|c|}
\hline \multirow[b]{2}{*}{ Variable } & \multirow[b]{2}{*}{ Cut off point } & \multirow[b]{2}{*}{$n$} & \multicolumn{4}{|c|}{ Survival } \\
\hline & & & $\%$ & $\begin{array}{l}\text { Median } \\
\text { time }\end{array}$ & $\begin{array}{l}\text { Mantel-Cox } \\
\text { statistic }\end{array}$ & $p$ value \\
\hline \multicolumn{7}{|l|}{ FIGO stage III and IV } \\
\hline Mean nuclear area $(\mu \mathrm{m})$ & $\begin{array}{l}\leq 75.8 \\
>75.8\end{array}$ & $\begin{array}{r}144 \\
36\end{array}$ & $\begin{array}{l}31 \\
19\end{array}$ & $\begin{array}{l}32 \\
20\end{array}$ & $8 \cdot 3$ & $0 \cdot 004$ \\
\hline SD of nuclear area & $\begin{array}{l}\leq 19.6 \\
>19.6\end{array}$ & $\begin{array}{r}118 \\
62\end{array}$ & $\begin{array}{l}35 \\
18\end{array}$ & $\begin{array}{l}43 \\
21\end{array}$ & $15 \cdot 8$ & $0 \cdot 0001$ \\
\hline \multicolumn{7}{|l|}{ FIGO stage III, RD $\leq 2 \mathrm{~cm}$} \\
\hline SD of nuclear area & $\begin{array}{l}\leq 20.8 \\
>20.8\end{array}$ & $\begin{array}{l}50 \\
17\end{array}$ & $\begin{array}{l}48 \\
29\end{array}$ & $\begin{array}{l}80 \\
29\end{array}$ & $5 \cdot 8$ & 0.02 \\
\hline \multicolumn{7}{|l|}{ FIGO stage III, RD $>2 \mathrm{~cm}$} \\
\hline Mitotic activity index & $\begin{array}{l}\leq 60 \\
>60\end{array}$ & $\begin{array}{l}36 \\
33\end{array}$ & $\begin{array}{l}28 \\
18\end{array}$ & $\begin{array}{l}31 \\
20\end{array}$ & $5 \cdot 0$ & $0 \cdot 03$ \\
\hline SD of nuclear area & $\begin{array}{l}\leq 21 \cdot 0 \\
>21 \cdot 0\end{array}$ & $\begin{array}{l}51 \\
18\end{array}$ & $\begin{array}{l}28 \\
11\end{array}$ & $\begin{array}{l}31 \\
20\end{array}$ & $4 \cdot 4$ & 0.04 \\
\hline
\end{tabular}

Table 4 Results of survival analysis of minimum spanning tree analysis in each of the relevant subgroups (FIGO stage III and residual disease (RD) less than $2 \mathrm{~cm}, F I G O$ stage III and RD greater than $2 \mathrm{~cm}, F I G O$ stage IV) (only variables that reached significance are listed)

\begin{tabular}{|c|c|c|c|c|c|c|}
\hline \multirow[b]{2}{*}{ Variable } & \multirow[b]{2}{*}{ Cut off point } & \multirow[b]{2}{*}{$n$} & \multicolumn{4}{|c|}{ Survival } \\
\hline & & & $\%$ & $\begin{array}{l}\text { Median } \\
\text { time }\end{array}$ & $\begin{array}{l}\text { Mantel-Cox } \\
\text { statistic }\end{array}$ & $p$ value \\
\hline \multicolumn{7}{|l|}{ FIGO stage III and IV } \\
\hline SD of line length & $\begin{array}{l}\leq 2.35 \\
>2.35\end{array}$ & $\begin{array}{l}10 \\
75\end{array}$ & $\begin{array}{l}33 \\
23\end{array}$ & $\begin{array}{l}36 \\
26\end{array}$ & $6 \cdot 1$ & $0 \cdot 01$ \\
\hline Connected to three nuclei (\%) & $\begin{array}{l}\leq 18.9 \\
>18.9\end{array}$ & $\begin{array}{l}95 \\
85\end{array}$ & $\begin{array}{l}34 \\
24\end{array}$ & $\begin{array}{l}40 \\
23\end{array}$ & $4 \cdot 4$ & 0.04 \\
\hline \multicolumn{7}{|l|}{ FIGO stage III, RD $\leq 2 \mathrm{~cm}$} \\
\hline $\mathrm{SD}$ of line length & $\begin{array}{l}\leq 2.35 \\
>2.35\end{array}$ & $\begin{array}{l}42 \\
25\end{array}$ & $\begin{array}{l}50 \\
32\end{array}$ & $\begin{array}{l}80 \\
35\end{array}$ & $5 \cdot 3$ & 0.02 \\
\hline \multicolumn{7}{|l|}{ FIGO stage III, RD $>2 \mathrm{~cm}$} \\
\hline Connected to three nuclei (\%) & $\begin{array}{l}\leq 19 \cdot 4 \\
>19 \cdot 4\end{array}$ & $\begin{array}{l}35 \\
34\end{array}$ & $\begin{array}{l}34 \\
12\end{array}$ & $\begin{array}{l}36 \\
20\end{array}$ & $7 \cdot 2$ & 0.007 \\
\hline Total line length $(\mu \mathrm{m})$ & $\begin{array}{l}\leq 278 \\
>278\end{array}$ & $\begin{array}{r}9 \\
27\end{array}$ & $\begin{array}{r}44 \\
0\end{array}$ & $\begin{array}{l}30 \\
16\end{array}$ & $6 \cdot 3$ & $0 \cdot 01$ \\
\hline Connected to one nucleus (\%) & $\begin{array}{l}\leq 28 \\
>28\end{array}$ & $\begin{array}{l}17 \\
19\end{array}$ & $\begin{array}{r}0 \\
21\end{array}$ & $\begin{array}{l}14 \\
24\end{array}$ & $5 \cdot 8$ & 0.02 \\
\hline
\end{tabular}


Table 5 Results of multivariate survival analysis of MST and other quantitative pathological variables in each of the relevant subgroups (FIGO stage III and residual disease (RD) less than $2 \mathrm{~cm}$, FIGO stage III and RD greater than $2 \mathrm{~cm}$, FIGO stage IV)

\begin{tabular}{|c|c|c|c|c|c|c|}
\hline \multirow[b]{2}{*}{ Variable } & \multirow[b]{2}{*}{ Cut off point } & \multirow[b]{2}{*}{$n$} & \multicolumn{4}{|c|}{ Survival } \\
\hline & & & $\%$ & $\begin{array}{l}\text { Median } \\
\text { time }\end{array}$ & $\begin{array}{l}\text { Mantel-Cox } \\
\text { statistic }\end{array}$ & p value \\
\hline $\begin{array}{l}\text { FIGO stage III and IV } \\
\text { FIGO, residual disease, } \\
\text { SD of nuclear area }\end{array}$ & $\begin{array}{l}\leq 3 \cdot 87 \\
3 \cdot 87-4 \cdot 76 \\
>4 \cdot 76\end{array}$ & $\begin{array}{l}46 \\
74 \\
52\end{array}$ & $\begin{array}{l}50 \\
27 \\
12\end{array}$ & $\begin{array}{l}80 \\
29 \\
17\end{array}$ & 35 & 0.00001 \\
\hline $\begin{array}{l}\text { FIGO stage III, } \mathrm{RD}<2 \mathrm{~cm} \\
\text { SD of nuclear area, } \mathrm{SD} \text { of } \\
\text { line length }\end{array}$ & $\begin{array}{l}\leq 1.35 \\
>1.35\end{array}$ & $\begin{array}{l}35 \\
32\end{array}$ & $\begin{array}{l}57 \\
28\end{array}$ & $\begin{array}{l}\mathrm{NR} \\
32\end{array}$ & $9 \cdot 1$ & 0.003 \\
\hline $\begin{array}{l}\text { FIGO stage III, RD }>2 \mathrm{~cm} \\
\text { SD of nuclear area, } \\
\text { Connected to three nuclei }(\%)^{\mathrm{c}}\end{array}$ & $\begin{array}{l}\leq 1.24 \\
>1.24\end{array}$ & $\begin{array}{l}26 \\
43\end{array}$ & $\begin{array}{l}42 \\
12\end{array}$ & $\begin{array}{l}50 \\
21\end{array}$ & 12 & 0.0006 \\
\hline
\end{tabular}

${ }^{\mathrm{a}}(0.8856 \times \mathrm{FIGO})+(0.6035 \times$ residual disease $)+(0.5993 \times \mathrm{SD}$ of nuclear area $), \mathrm{FIGO}=3$ or 4 , residual disease $=1$ or $2, \mathrm{SD}$ of nuclear area $\leq 19 \cdot 6=1$ or $>19 \cdot 6=2$.

${ }^{b}(0.6970 \times S D$ of nuclear area $)+(0.6394 \times S D$ of line length $), S D$ of nuclear area $\leq 20 \cdot 8=1$ or $>20 \cdot 8=2$, SD of line length

$\leq 2 \cdot 35=1$ or $>2 \cdot 35=2$.
c $(0.5414 \times \mathrm{SD}$ of nuclear area $)+(0.6861 \times$ connected to three nuclei $), \mathrm{SD}$ of nuclear area $\leq 21 \cdot 0=1$ or $>21 \cdot 0=2$, connected to three nuclei $\leq 19 \cdot 4 \%=1$ or $>19 \cdot 4 \%=2$.

$\mathrm{NR}=$ not reached the median survival time.

resulting formula was: $(0.6970 \times$ SDNA $)+$ $(0 \cdot 6394 \times$ SDLL), $($ SDNA $\leq 20 \cdot 8=1$ or $>20 \cdot 8=$ 2 , SDLL $\leq 2 \cdot 35=1$ or $>2 \cdot 35=2)$. The cut off point used $(1.35)$ revealed that in the 35 patients with a low score long term survival was achieved in $57 \%$, while in the group with a high score only $28 \%$ achieved long term survival (Mantel-Cox $=9 \cdot 1, \mathrm{p}=0.003$ ) (fig 2).

In patients with FIGO stage III disease and with residual disease $>2 \mathrm{~cm}$ in diameter $(\mathrm{n}=$ 67), the SDNA was selected first, followed by the percentage of points connected to three neighbouring nuclei (PCON3). The resulting formula was: $(0.5414 \times \mathrm{SDNA})+(0.6861 \times$ PCON3), (SDNA $\leq 21 \cdot 0=1$ or $>21 \cdot 0=2$, PCON $3 \leq 19 \cdot 4 \%=1$ or $>19 \cdot 4 \%=2$ ). The cut off point used $(1 \cdot 24)$ revealed that of 26 patients with a low score, $42 \%$ survived with a median survival time of 50 months, while in the group with a high score, only $12 \%$ survived with a median survival time of 21 months (Mantel$\operatorname{Cox}=12, \mathrm{p}=0.0006$ ).

In patients with FIGO stage IV disease the total line length (TLL) of the MST and the

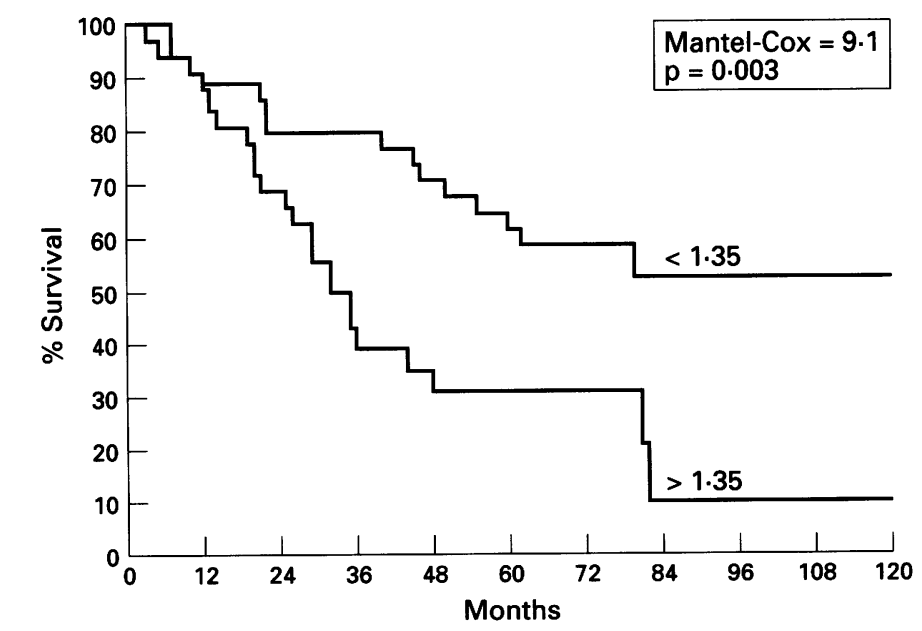

$\begin{array}{lllllllllllll}\text { At risk } & 35 & 32 & 28 & 28 & 24 & 21 & 14 & 8 & 4 & 1 & 0 & <1.35\end{array}$

Figure 2 Survival curves for subgroups with FIGO stage III and residual disease $<2 \mathrm{~cm}$, as determined by the multivariate prognostic index (cut off point $1 \cdot 35$ ), comprising the standard deviation of the nuclear area and line length of the MST. percentage of points connected to three neighbouring nuclei (PCON3) were selected in the Cox regression model. The resulting formula was: $\quad(1.4746 \times \mathrm{TLL})+(0.2272 \times \mathrm{PCON} 3)$, (TLL $\leq 278 \mu \mathrm{m}=1$ or $>278 \mu \mathrm{m}=2$; PCON3 selected as continuous variable). Using this score function the four surviving patients belonged to the group of patients $(n=5)$ with the lowest score when all values obtained were sorted. However, the small number of patients in this group prevented further statistical evaluation.

\section{Discussion}

In this study, a new prognostic index (FRS index), comprising the FIGO stage, the size of residual tumour after debulking surgery and the standard deviation of the nuclear area, provided highly significant prognostic information in patients with advanced ovarian carcinoma. The major advantage of this prognostic index is that it is based on objective, reproducible variables. The size of residual tumour after debulking surgery provided better prognostic information than the preoperative status, which is biologically understandable and in agreement with previous reports. ${ }^{10}{ }^{13}$ Indeed, large tumour nodules are less susceptible to cisplatin combination chemotherapy, possibly because of alterations in vascularisation, oxygenation and proliferation. ${ }^{112}$ Tumour nodules over $2 \mathrm{~cm}$ in diameter contain at least $10^{9}$ tumour cells and approximately 32 doublings will have taken place, inducing genetic liability which leads to the diversification of the dominant clone. ${ }^{3536}$ Accordingly, more DNA aneuploid cases occur and there is a greater likelihood that more aggressive, cisplatin resistant cell types will develop.

In this study the standard deviation of the nuclear area and line length of the MST showed important prognostic power. Therefore, it is likely that intratumour heterogeneity in nuclear size, as reflected by the standard deviation of the nuclear area, and a low grade of architectural differentiation in the tumour tissue, as reflected by the standard deviation of the line length of 
the MST, are important determinants of disease progression. The larger the variability in the size of nuclei and the more their arrangement in relation to one another is disturbed, the worse the prognosis will be. Therefore, we speculate that either different clones of tumour cells exist in advanced ovarian cancer or that they represent different steps in the process of malignant nuclear differentiation, which is more prominent in the tumours of patients who are likely to die of their disease. Indeed, the absence of any organisation in the arrangement of tumour nuclei may hamper vascularisation and thereby reduce the effectiveness of chemotherapy. As expected, patients with FIGO stage III disease and residual tumour nodes $<2 \mathrm{~cm}$ in diameter had a fairly good prognosis; however, clinical outcome in these groups was significantly less favourable when the standard deviations of nuclear area and line length of the MST were also high. Therefore, this prognostic index may be useful for predicting which patients are likely to benefit most from cisplatin combination chemotherapy and which are more likely to survive. Further prospective investigations are necessary to increase the sensitivity of this prognostic index.

The predictive value of quantitative pathological features (MNA, SDNA, MAI, VPE, and DNA ploidy) in the present study was not as good as in previous investigations. ${ }^{1316-22}$ This may be because a relatively large number of patients with FIGO stage IV disease $(20 \%)$, large tumours at diagnosis $(81 \%)$ and/or postoperative tumour nodules over $2 \mathrm{~cm}$ in diameter $(55 \%)$ were included in this study. The overall prognosis for these patients is very poor with current treatment regimens and therefore morphometric tumour characteristics may fail to predict a favourable outcome in these patients. The lack of prognostic significance of DNA ploidy assessed by flow cytometry may also be because of intratumour DNA heterogeneity in the large tumour masses, as has been found by other investigators. ${ }^{37-40}$

In this study no additional prognostic information was gained by estimating the $\bar{v}_{v}$ which is in agreement with the study performed by Mogensen et al. ${ }^{23}$ The correction for sampling problems as performed in the current investigation, using a systematic random sampling method within the least differentiated area, did not improve the prognostic power of this variable.

Clinical outcome in patients with advanced ovarian cancer is mainly determined by the FIGO stage and the outcome of debulking surgery. However, a subgroup of patients with a favourable prognosis can be identified among those with FIGO stage III disease and residual tumour $<2 \mathrm{~cm}$ in diameter using a new prognostic index based on the standard deviation of the nuclear area and line length of the MST. We conclude that morphometric variables have important additional value in predicting prognosis in patients with advanced ovarian cancer. Dr J Wils is kindly thanked for providing tissue. We also thank
Mrs M J van Oord for correcting the English. This work was supported by grant (28-834) from the Praeventiefonds.
1 Visser O, Coebergh JWW, Schouten LJ, eds. Incidence of cancer in the Netherlands 1990. Second report of the Netherlands Cancer Registry. Utrecht: Netherlands Cancer Registry, 1993.

$2 \mathrm{KjÆr}$ SK, Storm HH. Female genital organs. APMIS Suppl 1993;33:107-21.

3 Smith EM, Anderson B. The effects of symptoms and delay in seeking diagnosis on stage of disease at diagnosis among women with cancers of the ovary. Cancer 1985;56:272732.

4 Piver MS. Ovarian carcinoma: A decade of progress. Cancer 1984;54:2706-15.

5 Neijt JP, ten Bokkel Huinink WW, van der Burg MEL, van Oosterom AT, Vriesendorp R, Kooyman CD, et al. Randomised trial comparing two combination chemotherapy regimens (Hexa-CAF vs CHAP-5) in advanced therapy regimens (Hexa-CAF vs CHAP-5)

6 Richardson GS, Scully RE, Najamosama N, Nelson JH. Common epithelial cancer of the ovary. $N$ Engl f Med 1985;312:415-24.

7 Neijt JP, ten Bokkel Huinink WW, van der Burg MEL, van Oosterom AT, Willemse PHB, Vermorken JB, et al. Longterm survival in ovarian cancer: Mature data from the Netherlands Joint Study Group for Ovarian Cancer. Eur f Cancer 1991;27:1367-72.

8 Voest EE, van Houwelingen JC, Neijt JP. A meta-analysis of prognostic factors in advanced ovarian cancer with of prognostc factors in advanced Log (relative risk)) as main objectives. Eur $f$ Clin Oncol 1989;25:711-20.

9 van Houwelingen JC, ten Bokkel Huinink WW, van der Burg MEL, van Oosterom AT, Neijt JP. Predictability of the survival of patients with advanced ovarian cancer. $\mathcal{F}$ Clin Oncol 1989;7:769-73.

10 Lund B, Williamson P, van Houwelingen HC, Neijt JP. Comparison of the predictive power of different prognostic indices for overall survival in patients with advanced ovarian carcinoma. Cancer Res 1990;50:4626-9.

11 Folkman J, Watson $\mathrm{K}$, Ingber D, Hanahan D. Induction of angiogenesis during the transition from hyperplasia to angiogenesis during the transition

12 Tannock I. Cell kinetics and chemotherapy: a critical review. Cancer Treat Rep 1978;62:1117-33.

13 Rodenburg CJ, Cornelisse CJ, Hermans J, Fleuren GJ. DNA flow cytometry and morphometry as prognostic indicators in advanced ovarian cancer: A step forward in predicting the clinical outcome. Gynecol Oncol 1988;29:176-87.

14 Bichel P, Jakobsen A. A new histologic grading index in ovarian carcinoma. Int $\mathcal{f}$ Gynecol Pathol 1989;8:147-55.

15 Baak JPA, Langley FA, Talerman A, Delemarre JFM. The prognostic variability of ovarian tumour grading by different pathologists. Gynecol Oncol 1987;27:166-72.

16 Baak JPA, Schipper NW, Wisse-Brekelmans ECM, Ceelen Th, Bosman FT, van Geuns H, et al. The prognostic value of morphometrical features and cellular DNA content in cis-platin treated late ovarian cancer patients. Br $\mathcal{F}$ Cancer cis-platin treated

17 Haapasalo H, Collan Y, Atkin NB, Pesonen E, Seppä A. Prognosis of ovarian carcinomas: prediction by histoquantitative methods. Histopathology 1989;15:167-78.

18 Högberg T, Wang G, Risberg B, Guerrieri C, Hittson J, Boeryd B, et al. Nuclear morphometry: A strong prognostic factor for survival after secondary surgery in advanced ovarian cancer. Int $f$ Gynecol Cancer 1992;2:198-206.

19 Ludescher C, Weger A-R, Lindholm J, Oefner D, Hausmaninger $\mathrm{H}$, Reitsamer $\mathrm{R}$, et al. Prognostic significance of tumour cell morphometry, histopathology and clinical parameters in advanced carcinoma. Int $\mathcal{f}$ Gynecol Pathol parameters in a

20 van Diest PJ, Baak JPA, Brugghe J, van de Burg MEL, van Oosterom AT, Neijt JP. Quantitative pathologic features as predictors of long term survival in patients with advanced ovarian cancer treated with cisplatin. Int $\mathcal{f}$ Gynecol Cancer 1994;4:174-80.

21 Friedlander ML, Hedley DW, Swanson C, Russell P. Prediction of long term survival by flow cytometric analysis of cellular DNA content in patients with advanced ovarian of cellular DNA content in patients with

22 Rodenburg CJ, Ploem-Zaaijer JJ, Cornelisse CJ, Mesker WE, Hermans J, Heintz PA, et al. Use of DNA image cytometry in addition to flow cytometry for the study of patients with advanced ovarian cancer. Cancer Res 1987; 47:3938-41.

23 Mogensen O, Sørensen FB, Bichel P, Jakobsen A. Nuclear volume and prognosis in ovarian cancer. Int $\mathcal{f}$ Gynecol Cancer 1992;2:141-6.

24 Petersen SE. Setting up and running a microscope-based flow cytometer. Cytometry 1983;3:305-7.

25 Jakobsen A, Bichel P. Ploidy level, histopathological differentiation and response to chemotherapy in serous ovarian entiation and response to chemotherapy in serous o

26 Baak JPA, Chan KK, Stolk JG, Kenemans P. Prognostic factors in borderline and invasive ovarian tumours of the common epithelial type. Pathol Res Pract 1987;182: 755-74.

27 Baak JPA, van Diest PJ, Ariens ATH, van Beek MWPM, Bellot SM, Fijnheer J, et al. The multicenter morphometric mammary carcinoma project. A nationwide prospective study on reproducibility and prognostic power of routine quantitative assessments in the Netherlands. Pathol Res Pract 1989;185:664-70

28 Fleege JC, van Diest PJ, Baak JPA. Refinement and multiobserver evaluation of systematic random sampling to improve reproducibility in interactive nuclear morphometry. Anal Quant Cytol Histol 1993;15:281-9. 
29 Gundersen HJG, Jensen EB. Stereological estimation of the volume-weighted mean volume of arbitrary particles observed on random sections. 7 Microsc 1985;138:127-42.

30 Gundersen HJG, Bagger P, Bendtsen TF, Evans SM, Korbo L, Marcussen N, et al. The new stereological tools: Dissector, fractionator, nucleator and point sampled intercepts and their use in pathological research and diagnosis. APMIS 1988;96:857-81.

31 Gundersen HJG, Bendtsen TF, Korbo L, Marcussen N, Møller A, Nielsen K, et al. Some new, simple and efficient stereological methods and their use in pathological research and diagnosis. APMIS 1988;96:379-94.

32 Sørensen FB. Stereological estimation of the mean and variance of nuclear volume from vertical sections. $\mathcal{F}$ Microsc 1991;162:203-29.

33 Baak JPA, Ladekarl M, Sørensen FB. Reproducibility of mean nuclear volume and correlation with mean nuclear area in breast cancer. Hum Pathol 1994;25:80-5.

34 van Diest PJ, Fleege JC, Baak JPA. Syntactic structure analysis in breast cancer. Analysis of reproducibility, bio- logic background and prognostic value. Hum Pathol 1992; 23:876-83.

35 Hart IA, Saini A. Biology of tumour metastasis. Lancet 1992;339:1453-7.

36 Frost $\mathrm{P}$, Levin B. Clinical implications of metastatic process. Lancet 1992;339:1458-61.

37 Kallioniemi O. Comparison of fresh and paraffin-embedded tissue as starting material for DNA flow cytometry and evaluation of intratumor heterogeneity. Cytometry 1988;9: 164-9.

38 Zangwill BC, Balsara G, Dunton C, Varello M, Rebane BA, Hernandez E, Atkinson BF. Ovarian carcinoma heterogeneity as demonstrated by DNA ploidy. Cancer 1993;71: genel-7.

39 Kaern J, Tropé CG, Kristensen GB, Pettersen EO. Flow cytometric DNA ploidy and S-phase heterogeneity in advanced ovarian carcinoma. Cancer 1994;73:1870-7.

40 Takahashi Y, Takenaka A, Ishiguro T, Noda Y. Intratumoral DNA heterogeneity correlated with lymph node involvement and surgical staging in epithelial ovarian cancer by flow cytometry. Cancer 1994;73:3011-14. 